\title{
KECEMASAN IBU HAMIL TENTANG PELAYANAN ANTENATAL CARE DI ERA PANDEMI COVID-19
}

\author{
Kandace Sianipar $^{1 \mathrm{a})}$, Juneris Aritonang ${ }^{\left.2 b^{*}\right)}$, Wilda Wahyuni Siregar ${ }^{3 c}$ ) \\ ${ }^{1}$ Program Studi Kebidanan Pematangsiantar Poltekkes Kemenkes RI Medan \\ ${ }^{2}$ Universitas Sari Mutiara Indonesia \\ ${ }^{3}$ Institut Kesehatan Medistra Lubuk Pakam \\ a) kandace.sianipar06@gmail.com \\ $\mathrm{b}^{*}$ aritonangjuneris@ gmail.com \\ c)Wilda09wahyuni@gmail.com
}

Received: Januari 2021; Accepted: April 2021; Published: Juni 2021

\begin{abstract}
The provision of maternal services during the pandemic needs to be a concern to avoid an increase in maternal morbidity and mortality, especially at this time there are restrictions on maternal health services in the form of anxiety during pregnancy during the Covid19 pandemic. The type of research used in this study is descriptive which aims to determine the anxiety of pregnant women about ante natal care services in the era of the Covid-19 pandemic at the Bandar Khalipah Health Center in 2020. The population in this study were all pregnant women who did ANC checks in the Bandar Khalipah Health Center area. The sampling technique used in this study was accidental sampling (sampling when the study was conducted) totaled 34 people. The results of the study found that the majority of respondents had mild anxiety (44\%) about Ante Natal Care services in the Covid-19 pandemic era. From the results of this study, pregnant women should seek correct information about safe pregnancy during the Covid-19 pandemic so that they can change the anxiety of pregnant women about Ante Natal Care services in the Covid-19 pandemic era assisted by health workers in health education activities.

Keywords: Anxiety of pregnant women, antenatal care services, Covid-19 pandemic
\end{abstract}

ABSTRAK

Pemberian layanan maternal di masa pandemi perlu menjadi perhatian untuk menghindari terjadi peningkatan morbiditas dan mortalitas ibu, terlebih saat ini terdapat pembatasan pelayanan kesehatan maternal berupa kecemasan menjalani kehamilan selama pandemic Covid19. Jenis penelitian yang digunakan dalam penelitian ini adalah deskriptif yang bertujuan mengetahui kecemasan ibu hamil tentang pelayanan ante natal care diera pandemic Covid-19 di Puskesmas Bandar Khalipah tahun 2020. Populasi dalam penelitian ini adalah semua ibu hamil yang melakukan pemeriksaan ANC di wilayah Puskesmas Bandar Khalipah. Teknik pengambilan sampel dalam penelitain ini menggunakan accidental sampling (pengambilan sampel saat penelitian dilakukan) berjumlah 34 orang. Hasil peneliian didapati mayoritas responden memiliki kecemasan ringan (44\%) tentang pelayanan Ante Natal Care di era pandemi Covid-19. Dari hasil penelitian ini hendaknya ibu hamil mencari informasi yang benar tentang kehamilan yang aman di masa pandemic Covid-19 sehingga dapat merubah kecemasan ibu hamil tentang tentang pelayanan Ante Natal Care diera pandemi Covid-19 yang dibantu oleh petugas kesehatan dalam kegiatan-kegiatan pendidikan kesehatan.

Kata kunci: kecemasan, ibu hamil, pelayanan antenatal care, pandemic Covid-19 
Online: http://e-journal.sari-mutiara.ac.id/index.php/KesehatanMasyarakat

DOI: https://doi.org/10.51544/jkmlh.v6i1.1962

\section{PENDAHULUAN}

Indonesia merupakan salah satu negara yang terjangkit pandemi Corona Virus Disease-19 (Covid-19) dengan angka kejadian terkonfirmasi Covid-19 (kasus baru) yang bertambah secara fluktuatif (Purnamasari \& Raharyani, 2020). Covid-19 pertama kali diumumkan oleh WHO pada akhir tahun 2019 sebagai penyakit menular yang disebabkan virus corona (Virus SARSCOV 2) (Chai et al., 2020). Awalnya Covid19 dilaporkan mayoritas menyerang kelompok lanjut usia, namun belakangan ini dilaporkan juga telah menyerang kelompiok usia lainnya (bayi, balita, remaja, usia produktif dan kelompok ibu hamil). Terjadinya perubahan fisiologis pada masa kehamilan mengakibatkan kekebalan parsial menurun sehingga dapat berdampak serius pada ibu hamil, hal ini penyebab ibu hamil dijadikan kelompok rentan resiko terinfeksi Covid-19 (Liang \& Acharya, 2020).

Situasi pandemi Covid-19 ini meningkatkan kecemasan ibu hamil, bukan saja mencemaskan keadaan janinnya tetapi juga mencemaskan apakah ibu dan janin akan sehat bebas infeksi Covid-19, aman atau tidaknya dalam pemeriksaan kehamilan selama masa pandemi. Pemerintah dan berbagai lembaga telah melakukan upayaupaya berupa sosialisasi mengenai Covid-19 termasuk pencegahan penularan tetapi masih banyak masyarakat yang belum memahaminya. Terjadinya keadaan tersebut dikarenakan informasi palasu (hoax) yang banyak beredar dimasyarakat. Kehamilan yang disertai dengan kecemasan akan menurunkan imun ibu sehingga ibu hamil akan semakin rentan terinfeksi Covid-19.

Pemberian layanan maternal di masa pandemi perlu menjadi perhatian untuk menghindari terjadi peningkatan morbiditas dan mortalitas ibu, terlebih saat ini terdapat pembatasan pelayanan kesehatan maternal. Seperti ibu hamil menjadi enggan ke puskesmas atau fasiltas pelayanan kesehatan lainnya karena takut tertular, adanya anjuran menunda pemeriksaan kehamilan dan kelas ibu hamil, serta adanya ketidaksiapan layanan dari segi tenaga dan sarana prasarana termasuk alat pelindung diri. Untuk mengantisipasi perburukan layanan ibu hamil di masa pandemi Covid-19 maka dibutuhkan panduan pelayanan baik untuk ibu hamil bukan Covid-19, maupun ibu hamil yang dicurigai terinfeksi Covid-19.

Studi pendahuluan yang dilakukan oleh peneliti pada bulan Nopember 2020 di Puskesmas Bandar Khalipah diperoleh data cakupan K4 pada tahun 2018 yaitu 67,78\% (61\% ibu hamil dari sasaran 90\%) pada tahun 2019 cakupan K4 berjumlah 84,34\% (70\% ibu hamil dari sasaran sebesar $83 \%$ ). Sementara itu cakupan K4 hingga bulan Oktober 2020 yaitu 80,88\% (55\% ibu hamil dengan sasaran 68\%). Hasil dari studi pendahuluan ini yang melatarbelakangi peneliti ingin melakukan penelitian tentang hubungan rendahnya cakupan K4 dengan situasi pandemi di Puskesmas Bandar Khalipah tahun 2020. Berdasarkan hal diatas maka peneliti tertarik untuk meneliti tentang kecemasan ibu hamil tentang pelayanan ante natal care di era pandemi Covid-19 di Puskesmas Bandar Khalipah tahun 2020"

\section{METODE PENELITIAN}

Penelitian ini adalah penelitian deskriptif yang bertujuan untuk mengetahui kecemasan dan kecemasan ibu hamil tentang pelayanan ante natal care diera pandemi covid 19 di Puskesmas Bandar Khalipah tahun 2020. Populasi dalam penelitian ini adalah semua ibu hamil yang melakukan pemeriksaan ANC di wilayah Puskesmas Bandar Khalipah berjumlah 67 orang. 
Online: http://e-journal.sari-mutiara.ac.id/index.php/KesehatanMasyarakat

DOI: https://doi.org/10.51544/jkmlh.v6i1.1962

Sampel pada penelitian ini adalah ibu hamil yang melakukan pemeriksaan ANC di wilayah Puskesmas Bandar Khalipah dengan kriteria memiliki ibu memiliki buku KIA dan pada saat kunjungan tersebut adalah kunjungan $\mathrm{K} 4$, tehnik pengambilan sampel dengan accidental sampling (pengambilan sampel saat penelitian dilakukan) berjumlah 34 orang.

\section{HASIL PENELITIAN DAN PEMBAHASAN}

Hasil penelitian didapati tentang kecemasan ibu hamil pada pelayanan Ante Natal Care di era pandemi Covid 19 Di Puskesmas Bandar Khalipah Tahun 2021 yang dapat dilihat pada tabel 1 dibawah ini:

Tabel 1. Kecemasan Ibu Hamil Tentang Pelayanan Ante Natal Care Diera Pandemi Covid-19 Di Puskesmas Bandar Khalipah Tahun 2021

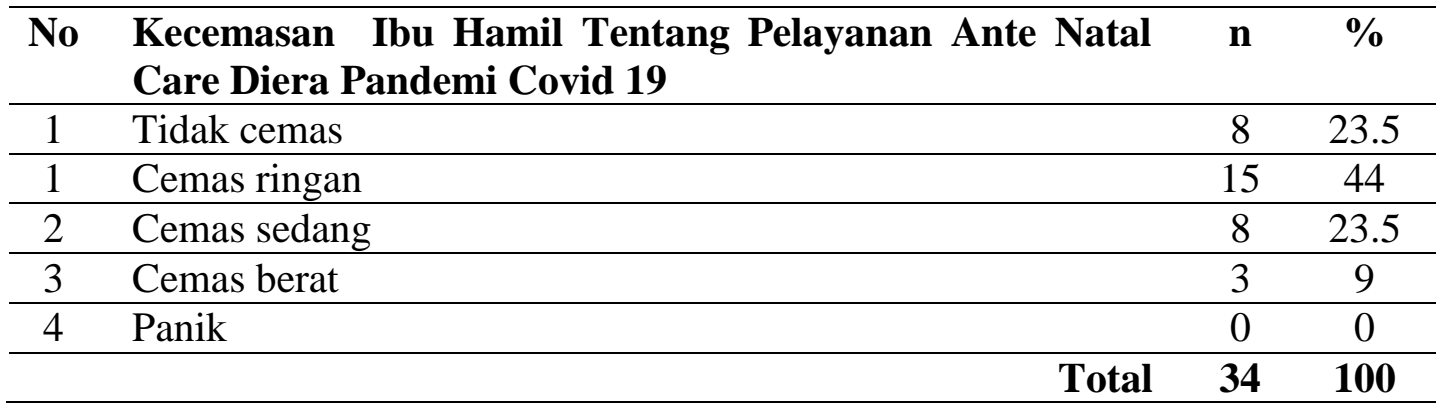

Didapati bahwa dari 34 responden didapati mayoritas cemas ringan (44 \%) tentang pelayanan Ante Natal Care diera pandemi Covid 19 Di Puskesmas Bandar Khalipah Tahun 2021.

Kasus Corona Virus di Indonesia sebesar 165.887 jiwa dengan jumlah kematian yaitu 4,3\% . Kasus tersebut menyerang semua kalangan, salah satunya adalah ibu hamil (Direktorat Kesehatan Keluarga, 2020). Hal ini menyebabkan ibu hamil mengalami rasa cemas bahkan sampai mengalami depresi serta dapat meningkatkan jumlah kematian. Hasil studi menunjukkan bahwa ibu hamil yang mengalami rasa cemas bahkan sampai stres diakibatkan karena berbagai macam masalah diantaranya adalah ekonomi, keluarga, pekerjaan, serta kekhawatiran terhadap kehamilan itu sendiri dan persalinan (Nurhasanah, 2020).

Faktor kesiapan ibu dalam menghadapi persalinan saat pandemi Covid-19 menjadi salah satu dampak ibu mengalami rasa cemas yang berlebihan. Kemungkinan ini disebabkan karena ibu terlalu khawatir dengan keadaan janin setelah lahir akan tertular oleh penyakit virus Corona sehingga berdampak pada kesehatan bayinya. Penyebaran virus Corona ini memang sangat cepat dan berdampak buruk terhadap kesehatan penderitanya. Akan tetapi penyebaran virus tersebut bisa dilakukan dengan beberapa pencegahan. Perlu adanya pemahaman bagi ibu hamil dalam penyebaran Covid-19 agar mereka memhami dengan benar bahwa virus tersebut bisa diantisipasi dengan melakukan beberapa hal pencegahan 
Online: http://e-journal.sari-mutiara.ac.id/index.php/KesehatanMasyarakat

DOI: https://doi.org/10.51544/jkmlh.v6i1.1962

salah satunya sering mencuci tangan dan memakai masker. Pemahaman yang rendah pada ibu hamil tentang upaya pencegahan infeksi Covid-19 selama kehamilan dikarenakan adanya informasiinformasi yang palsu di masyarakat luas mengenai penularan, pengobatan dan pencegahan tertularnya Covid-19 (Saputra, 2020).

Dalam hal ini pandemi covid menjadi salah satu awal mula sumber permasalahan tersebut. Selain itu, mengakibatkan layanan kesehatan maternal dan neonatal dibatasi, misalnya seperti adanya pengurangan frekuensi pemeriksaan kehamilan dan kelas ibu hamil tertunda. Keadaan tersebut menyebabkan permasalahan secara psikologi yaitu rasa cemas pada ibu hamil. Salah satu studi penelitian mengatakan bahwa ibu hamil hamil mengalami gejala depresif dan dan kecemasan lebih tinggi saat adanya pandemi covid-19 dibandingkan sebelumnya, termasuk kecendungan ingin melukai dirinya sendiri (Wu et al., 2020). Dalam kondisi tersebut, menimbulkan kondisi bahaya selama kehamilan sehingga dapat berpengaruh terhadap kesehatan ibu dan janinnya (Durankuş \& Aksu, 2020)(Cameron et al., 2020).

Menurut penulis, dari hasil penelitian ini ditemukan mayoritas responden memiliki kecemasan ringan disebabkan karena kurangnya pengetahuan ibu tentang kehamilan yang aman di masa pandemic Covid19. Hasil penelitian tersebut juga yang dapat mempengaruhi tingkat kecemasan ibu hamil. Meskipun dalam penelitian ini tidak dilakukan penelitian hingga tahap tersebut.

\section{SIMPULAN}

Mayoritas responden cemas ringan (44\%) tentang pelayanan Ante Natal Care diera pandemi Covid 19 Di Puskesmas Bandar Khalipah Tahun 2021

\section{SARAN}

1. Meningkatkan pengetahuan ibu hamil tentang kehamilan yang aman di masa pandemic Covid-19 sehingga dapat merubah kecemasan ibu hamil tentang tentang pelayanan Ante Natal Care diera pandemi Covid-19

2. Mencari informasi yang benar tentang kehamilan yang aman di masa pandemic Covid-19 sehingga dapat merubah kecemasan ibu hamil tentang tentang pelayanan Ante Natal Care diera pandemi Covid-19

\section{DAFTAR PUSTAKA}

Cameron, E. E., Joyce, K. M., Delaquis, C. P., Reynolds, K., Protudjer, J. L. P., \& Roos, L. E. (2020). Maternal psychological distress \& mental health service use during the COVID-19 pandemic. Journal of Affective Disorders. https://doi.org/10.1016/j.jad.2020.07.08 1

Chai, K. L., Valk, S. J., Piechotta, V., Kimber, C., Monsef, I., Doree, C., Wood, E. M., Lamikanra, A. A., Roberts, D. J., McQuilten, Z., al., et, Singh, B. C., Ryan, H., Kredo, T., Chaplin, M., Fletcher, T., Boutron, I., Chaimani, A., Devane, D., ... NCT04647669. (2020). Preventing Pulmonary Complications in Surgical Patients at Risk of COVID-19. Clinicaltrials.Gov.

Direktorat Kesehatan Keluarga. (2020). Pedoman Bagi Ibu Hamil, Ibu Nifas, 
Online: http://e-journal.sari-mutiara.ac.id/index.php/KesehatanMasyarakat

DOI: https://doi.org/10.51544/jkmlh.v6i1.1962

dan Bayi Baru Lahir Di Era Pandemi Covid-19. Kementrian Kesehatan RI.

Durankuş, F., \& Aksu, E. (2020). Effects of the COVID-19 pandemic on anxiety and depressive symptoms in pregnant women: a preliminary study. Journal of Maternal-Fetal and Neonatal Medicine.

https://doi.org/10.1080/14767058.2020. 1763946

Liang, H., \& Acharya, G. (2020). Novel corona virus disease (COVID-19) in pregnancy: What clinical recommendations to follow? Acta Obstetricia et Gynecologica Scandinavica. https://doi.org/10.1111/aogs.13836

Nurhasanah, I. (2020). Jurnal Bidan Komunitas. Hubungan Pola Asuh Orangtua Dengan Status Gizi Pada Balita Di Wilayah Kerja Puskesmas Bulang Kota Batam.

Purnamasari, I., \& Raharyani, A. E. (2020). Tingkat Pengetahuan dan Perilaku Masyarakat Kabupaten Wonosobo Tentang Covid-19. Jurnal Ilmiah Kesehatan, 10(1), 33-42. https://ojs.unsiq.ac.id/index.php/jik/arti cle/view/1311

Saputra, D. (2020). Fenomena Informasi Palsu ( Hoax ) Pada Media Sosial di Tengah Pandemi Covid-19 dalam Perspektif Islam Devid Saputra. Mau'idhoh Hasanah: Jurnal Dakwah Dan Ilmu Komunikasi.

Wu, F., Zhao, S., Yu, B., Chen, Y. M., Wang, W., Song, Z. G., Hu, Y., Tao, Z. W., Tian, J. H., Pei, Y. Y., Yuan, M. L., Zhang, Y. L., Dai, F. H., Liu, Y., Wang, Q. M., Zheng, J. J., Xu, L., Holmes, E. C., \& Zhang, Y. Z. (2020). A new coronavirus associated with human respiratory disease in China.
Nature. https://doi.org/10.1038/s41586020-2008-3

Yuliani, D. R., \& Aini, F. N. (2020). Kecemasan Ibu Hamil Dan Ibu Nifas Pada Masa Pandemi Covid-19 Di Kecamatan Baturraden. Jurnal Sains Kebidanan. https://doi.org/10.31983/jsk.v2i2.6487

Cameron, E. E., Joyce, K. M., Delaquis, C. P., Reynolds, K., Protudjer, J. L. P., \& Roos, L. E. (2020). Maternal psychological distress \& mental health service use during the COVID-19 pandemic. Journal of Affective Disorders.

https://doi.org/10.1016/j.jad.2020.07.08 1

Chai, K. L., Valk, S. J., Piechotta, V., Kimber, C., Monsef, I., Doree, C., Wood, E. M., Lamikanra, A. A., Roberts, D. J., McQuilten, Z., al., et, Singh, B. C., Ryan, H., Kredo, T., Chaplin, M., Fletcher, T., Boutron, I., Chaimani, A., Devane, D., ... NCT04647669. (2020). Preventing Pulmonary Complications in Surgical Patients at Risk of Covid-19. Clinicaltrials.Gov.

Direktorat Kesehatan Keluarga. (2020). Pedoman Bagi Ibu Hamil, Ibu Nifas, dan Bayi Baru Lahir Di Era Pandemi Covid-19. Kementrian Kesehatan RI.

Durankuș, F., \& Aksu, E. (2020). Effects of the Covid-19 pandemic on anxiety and depressive symptoms in pregnant women: a preliminary study. Journal of Maternal-Fetal and Neonatal Medicine.

https://doi.org/10.1080/14767058.2020. 1763946

Liang, H., \& Acharya, G. (2020). Novel corona virus disease (Covid-19) in pregnancy: What clinical 
Online: http://e-journal.sari-mutiara.ac.id/index.php/KesehatanMasyarakat

DOI: https://doi.org/10.51544/jkmlh.v6i1.1962

recommendations to follow? Acta

Obstetricia et Gynecologica

Scandinavica.

https://doi.org/10.1111/aogs.13836

Nurhasanah, I. (2020). Jurnal Bidan Komunitas. Hubungan Pola Asuh Orangtua Dengan Status Gizi Pada Balita Di Wilayah Kerja Puskesmas Bulang Kota Batam.

Purnamasari, I., \& Raharyani, A. E. (2020). Tingkat Pengetahuan dan Perilaku Masyarakat Kabupaten Wonosobo Tentang Covid-19. Jurnal Ilmiah Kesehatan, 10(1), 33-42. https://ojs.unsiq.ac.id/index.php/jik/arti cle/view/1311

Saputra，D. (2020). Fenomena Informasi Palsu ( Hoax ) Pada Media Sosial di Tengah Pandemi Covid-19 dalam
Perspektif Islam Devid Saputra Mau'idhoh Hasanah: Jurnal Dakwah Dan Ilmu Komunikasi.

Wu, F., Zhao, S., Yu, B., Chen, Y. M., Wang, W., Song, Z. G., Hu, Y., Tao, Z. W., Tian, J. H., Pei, Y. Y., Yuan, M. L., Zhang, Y. L., Dai, F. H., Liu, Y., Wang, Q. M., Zheng, J. J., Xu, L., Holmes, E. C., \& Zhang, Y. Z. (2020). A new coronavirus associated with human respiratory disease in China. Nature. https://doi.org/10.1038/s41586020-2008-3

Yuliani, D. R., \& Aini, F. N. (2020). Kecemasan Ibu Hamil Dan Ibu Nifas Pada Masa Pandemi Covid-19 Di Kecamatan Baturraden. Jurnal Sains Kebidanan.

https://doi.org/10.31983/jsk.v2i2.6487 